\title{
STRUKTUR KOMUNITAS LAMUN \\ DI MALANG RAPAT, BINTAN
}

\author{
Wahyu Adi ${ }^{1}$, Aditya Hikmat Nugraha ${ }^{2}$, Yehiel Hendry Dasmasela ${ }^{3}$, \\ Agus Ramli ${ }^{4}$, Calvyn Fredrik Aldus Sondak ${ }^{5}$, Nurul Dhewani Mirah \\ Sjafrie $^{6}$ \\ ${ }^{1}$ Program Studi Manajemen Sumberdaya Perairan, Universitas Bangka \\ Belitung, Kepulauan Bangka Belitung, Indonesia \\ ${ }^{2}$ Fakultas IImu Kelautan dan Perikanan, Universitas Maritim Raja Ali \\ Haji, Tanjung Pinang, Indonesia \\ ${ }^{3}$ Fakultas Perikanan dan IImu Kelautan, Universitas Papua,Manokwari, \\ Indonesia \\ ${ }^{4}$ Pusat Kajian Sumberdaya Pesisir dan Lautan, Institut Pertanian Bogor, \\ Bogor, Indonesia \\ ${ }^{5}$ Program Studi Ilmu Kelautan, Universitas Sam Ratulangi, Manado, \\ Indonesia \\ ${ }^{6}$ Pusat Penelitian Oseanografi Lembaga IImu Pengetahuan Indonesia, \\ Jakarta, Indonesia \\ E-mail : emailwahyuadi@gmail.com
}

Received May 2019, Accepted September 2019

\begin{abstract}
ABSTRAK
Padang lamun menyediakan banyak manfaat. Diperlukan penilaian tutupan lamun dan distribusi spasial spesies lamun, untuk memastikan manfaat dari padang lamun tetap ada. Penelitian ini dilakukan dengan metode kuadran disepanjang line transect, dan analisis data dilakukan untuk dapat menyajikan informasi tentang titik koordinat transek garis, persen tutupan lamun, persen tutupan spesies lamun, jenis substrat (pasir, lumpur dan pecahan karang), jumlah spesies Enhallus acoroides (tegakan $/ \mathrm{m}^{2}$ ) dan distribusi spasial spesies lamun. Hasil penelitian menunjukkan kondisi padang lamun di wilayah studi sebagai kategori tutupan padat. Spesies lamun Thalassia hemprichii (Th) dan Enhalus acoroides (Ea) adalah spesies dominan dan menyebar ke seluruh wilayah penelitian.
\end{abstract}

Kata Kunci : Lamun, Bintan, Malang Prapat, Persen Tutupan

\section{ABSTRACT}

COMMUNITY STRUCTURE OF SEAGRASS IN MALANG RAPAT, BINTAN. Seagrass beds provide many benefits. Assessment of seagrass cover and spatial distribution of seagrass species is needed, to ensure the 
benefits of seagrass beds remain. The study was conducted using the quadratic method on the line transect, and the analysis was carried out to be able to present information about line transect coordinate points, percent cover of seagrass, percent cover of seagrass species, substrate type (sand, mud and rubble), number of species of Enhallus acoroides $\left(\right.$ shoot $\left./ \mathrm{m}^{2}\right)$ and spatial distribution of seagrass species. The results showed the condition of seagrass beds in the study area as a category of solid cover. Seagrass species Thalassia hemprichii (Th) and Enhalus acoroides (Ea) are dominant species and spread throughout the study area.

Keywords : Seagrass, Bintan, Malang Rapat, Percent Cover

\section{PENDAHULUAN}

Padang Lamun bermanfaat bagi ikan sebagai tempat menyediakan makanan, tempat pemijahan, tempat pengasuhan larva dan habitat ikan, di Bali (Tanjung Benoa) ditemukan 21 famili ikan yang berasosiasi dengan setidaknya 3 sampai 7 jenis lamun (Faiqoh et.al., 2017), di Bangka Selatan dilaporkan selain terdapat bivalvia ditemukan juga 25 spesies ikan yang berasosiasi dengan 6 jenis lamun (Prisilia, 2018; Febrina, 2018), sedangkan di Makasar (Pulau Barranglompo) didapatkan 19 spesies dan 18 famili ikan di padang lamun (Supriadi et al, 2004). Bagi gastropoda, jenis Strombus turturella atau dikenal dengan nama siput gonggong, Halophilla minor menjadi pilihan untuk habitat hidup (Supratman dan Syamsudin, 2016). Pada Pulau Kei Kecil (Maluku Tenggara) terdapat 103 spesies moluska (80 gastropoda; 23 bivalve) juga berhabitat di padang lamun (Kusnadi et al, 2008). Epifauna juga ditemukan oleh Prakoso (2015) didaerah lamun Pulau Pahawang (Lampung), terutama jenis Cerithium $s p$ dan Cronia $s p$. Fungsi lamun sebagai sumber energi saat dimakan oleh Dugong (Dugong dugon) dijelaskan didalam penelitian Sjafrie (2018), dari hasil perhitungan didaerah Bintan (Kepulauan Riau), Desa Pengudang dan Berakit mampu memberi makan ratusan dugong. Secara ekonomis dijelaskan oleh Wawo (2014), padang lamun memiliki nilai dari jasa ekosistem sebesar IDR 21.014.755.749, nilai yang besar apabila pengelolaan lamun terus dikembangkan dan diperhatikan. Fungsi bioakumulasi logam berat ditunjukkan oleh Nugraha et al, (2017), logam berat yang terbanyak diserap adalah $\mathrm{Pb}$ pada lamun Enhallus acoroides.

Manfaat lamun ini perlu dipertahankan, dengan cara memantau kondisi padang lamun dan mengurangi efek dari penyebab penurunan lamun. Menurut Rahmawati (2011) dan Unsworth et al. (2018) ada beberapa penyebab penurunan lamun, antara lain eutrofikasi, pengendapan (siltation), pembebanan sedimen organik, bahan kimia beracun, perubahan fisika kimia, kerusakan mekanis, invasi oleh jenis eksotis, pemanasan global, reklamasi lahan, penebangan hutan, overfishing dan pembuangan sampah

Penelitian ini bertujuan untuk melihat kondisi tutupan padang lamun dan sebaran jenis di daerah Malang Rapat. Diharapkan dengan 
menerapkan metode pengamatan padang lamun yang ditulis Rahmawati et al. (2017) dan penggunaan software ArcGIS dapat membantu pelaksanaan penelitian.

\section{MATERI DAN METODE}

\section{Waktu dan Lokasi}

Pengambilan data lapangan (padang lamun) dilakukan pada tanggal bulan April tahun 2019. Pengamatan kondisi padang lamun dilakukan di Desa Malang Rapat, Kecamatan Gunung Kijang, Kabupaten Bintan (Gambar 1 dan Tabel 1).

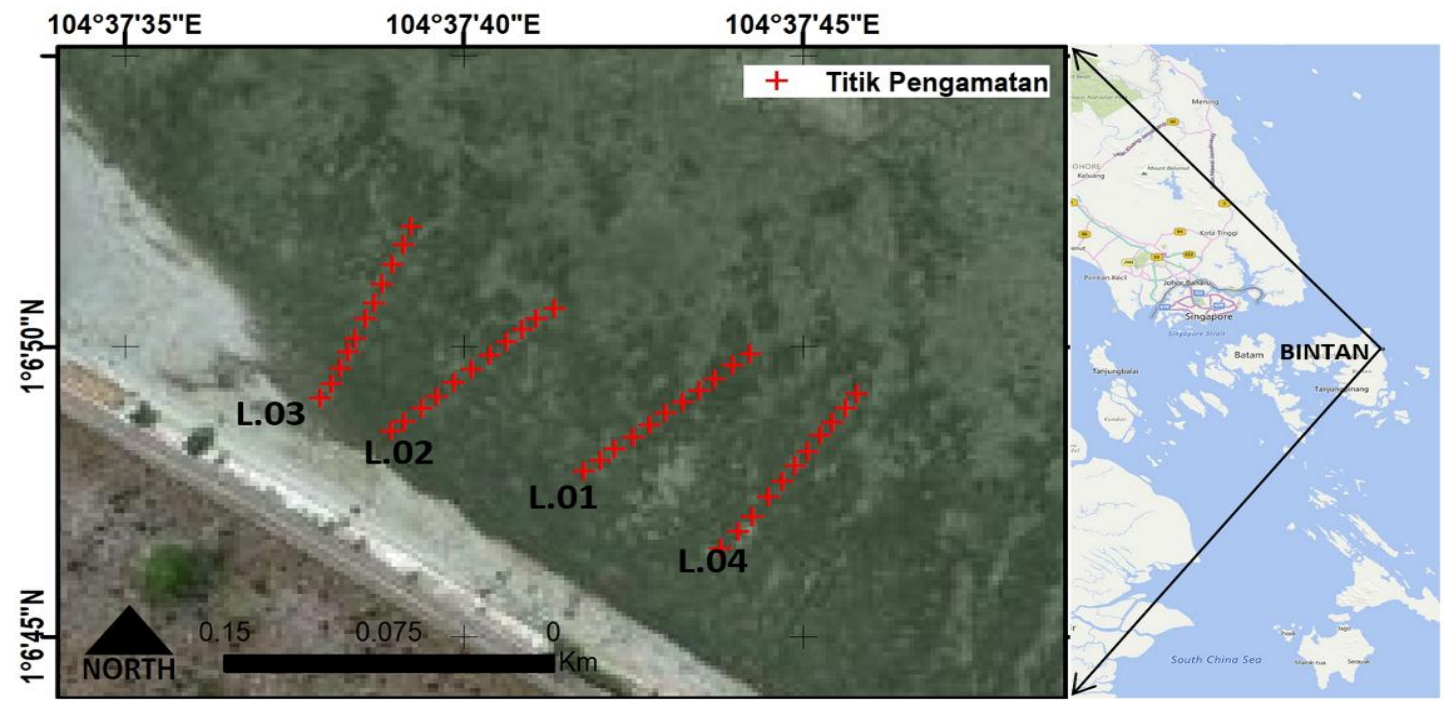

Gambar 1. Lokasi Pengamatan.

Tabel 1. Titik Pengamatan

\begin{tabular}{ll}
\hline $\begin{array}{l}\text { Garis } \\
\text { Transek }\end{array}$ & Titik Kordinat \\
\hline L.01 & $\mathrm{N} 1.11329^{\circ}, \mathrm{E} 104.62827^{\circ}$ sampai dengan N $1.11385^{\circ}, \mathrm{E}$ \\
& $104.62895^{\circ}$ \\
$\mathrm{L} .02$ & $\mathrm{~N} 1.11348^{\circ}, \mathrm{E} 104.62748^{\circ}$ sampai dengan N $1.11407^{\circ}, \mathrm{E}$ \\
& $104.62815^{\circ}$ \\
$\mathrm{L} .03$ & $\mathrm{~N} 1.11364^{\circ}, \mathrm{E} 104.62719^{\circ}$ sampai dengan N $1.11446^{\circ}, \mathrm{E}$ \\
& $104.62756^{\circ}$ \\
$\mathrm{L} .04$ & $\mathrm{~N} 1.11292^{\circ}, \mathrm{E} 104.62883^{\circ}$ sampai dengan N $1.11366^{\circ}, \mathrm{E}$ \\
& $104.62939^{\circ}$
\end{tabular}

\section{Materi}

Materi dalam penelitian ini adalah lamun yang berada di lokasi penelitian serta peralatan pribadi (celana panjang dan baju lengan panjang, sarung tangan, sepatu koral dan alat selam dasar) Alat Global 
Positioning System (GPS), Roll meter $100 \mathrm{~m}$, transek kuadrat $50 \times 50 \mathrm{~cm}^{2}$ (di dalam kuadrat dibagi menjadi 4 kotak kecil), lembar kerja dan alat tulis, dan peralatan lain yang dianggap membantu pengamatan.

Penelitian menggunakan software dan data Google Earth untuk menggambarkan ilustrasi pengambilan data, selain itu software ArcGIS digunakan juga untuk interpolasi kemunculan spesies di lokasi pengamatan

\section{Metode Pengambilan Data}

Pengambilan data dilakukan pada transek garis dengan panjang masing-masing $100 \mathrm{~m}$. Transek kuadrat diletakkan di sisi kanan transek garis dengan jarak antara transek kuadrat satu dengan yang lainnya adalah $10 \mathrm{~m}$.

Pengambilan data meliputi; titik kordinat transek garis, persentase penutupan lamun, persentase penutupan spesies lamun, jenis substrat (pasir, lumpur dan pecahan karang/ rubble), jumlah tegakan jenis Enhallus acoroides (tegakan/ $\mathrm{m}^{2}$ )

\section{Analisis Data}

1. Penutupan lamun, dengan cara menjumlah penutupan lamun setiap kuadrat. Penutupan lamun dalam satu kuadrat, dengan menjumlah nilai penutupan lamun pada setiap kotak kecil dalam kuadrat dan membaginya dengan jumlah kotak kecil, yaitu 4 (empat).

2. Penutupan lamun per jenis. Penutupan lamun per jenis dihitung untuk menentukan jenis lamun yang paling dominan pada satu lokasi/ pulau berdasarkan persentase penutupannya. Cara menghitung penutupan lamun per jenis lamun dalam satu stasiun adalah menjumlah nilai persentase penutupan setiap jenis lamun pada setiap kuadrat seluruh transek dan membaginya dengan jumlah kuadrat pada stasiun tersebut.

3. Penilaian kondisi padang lamun mengacu pada buku Panduan Pemantauan Padang Lamun (Rahmawati et al, 2017). Kategori tutupan lamu dapat dilihat pada Tabel 2.

Tabel 2. Kategori tutupan lamun

\begin{tabular}{ll}
\hline Tutupan Lamun (\%) & Kategori \\
\hline $0-25$ & Jarang \\
$26-50$ & Sedang \\
$51-75$ & Padat \\
$76-100$ & Sangat Padat \\
\hline
\end{tabular}

Sumber : Rahmawati et al., 2017

4. Sebaran Jenis lamun di lokasi pengamatan, dilakukan dengan interpolasi (IDW) data pada titik pengamatan menggunakan software ArcGis. 


\section{HASIL DAN PEMBAHASAN}

Titik pengamatan/ lokasi penelitian berada di Desa Malang Rapat, secara umum merupakan daerah berpasir landai dekat dengan jalan raya, jauh dari pemukiman dan muara sungai. Aktivitas masyarakat menambatkan "Kelong" dan kegiatan pengerukan pasir menggunakan alat berat terlihat didaerah barat laut dari titik pengamatan. Kedalaman pengamatan berkisar antara $10-50 \mathrm{~cm}$, kecerahan perairan $100 \%$ (terlihat sampai dasar). Pengamatan dilakukan saat cuaca cerah, dengan waktu pengamatan siang hari (jam 10.00 - 12.00 WIB). Vegetasi mangrove terlihat yang bersifat asosiasi saja (kelapa, ketapang, pandan laut, dll).

Hasil analisis data lapangan didapatkan bahwa total penutupan lamun adalah 53,77\%, sedangkan jenis Thalassia hemprichii (Th) dan Enhalus acoroides (Ea) merupakan spesies yang dominan ditemukan didaerah pengamatan. Tujuh spesies yang ditemukan pada lokasi penelitian antara lain $\mathrm{Ea}=$ Enhalus acoroides, $\mathrm{Th}=$ Thalassia hemprichii, $\mathrm{Cs}=$ Cymodocea serrulata, $\mathrm{Cr}=$ Cymodocea rotundata, $\mathrm{Hu}=$ Halodule uninervis, $\mathrm{Hd}=$ Halophila decipiens, $\mathrm{Si}=$ Syringodium isoetifolium. Persentase tutupan lamun dapat dilihat pada Gambar 2 dan Tabel 3.

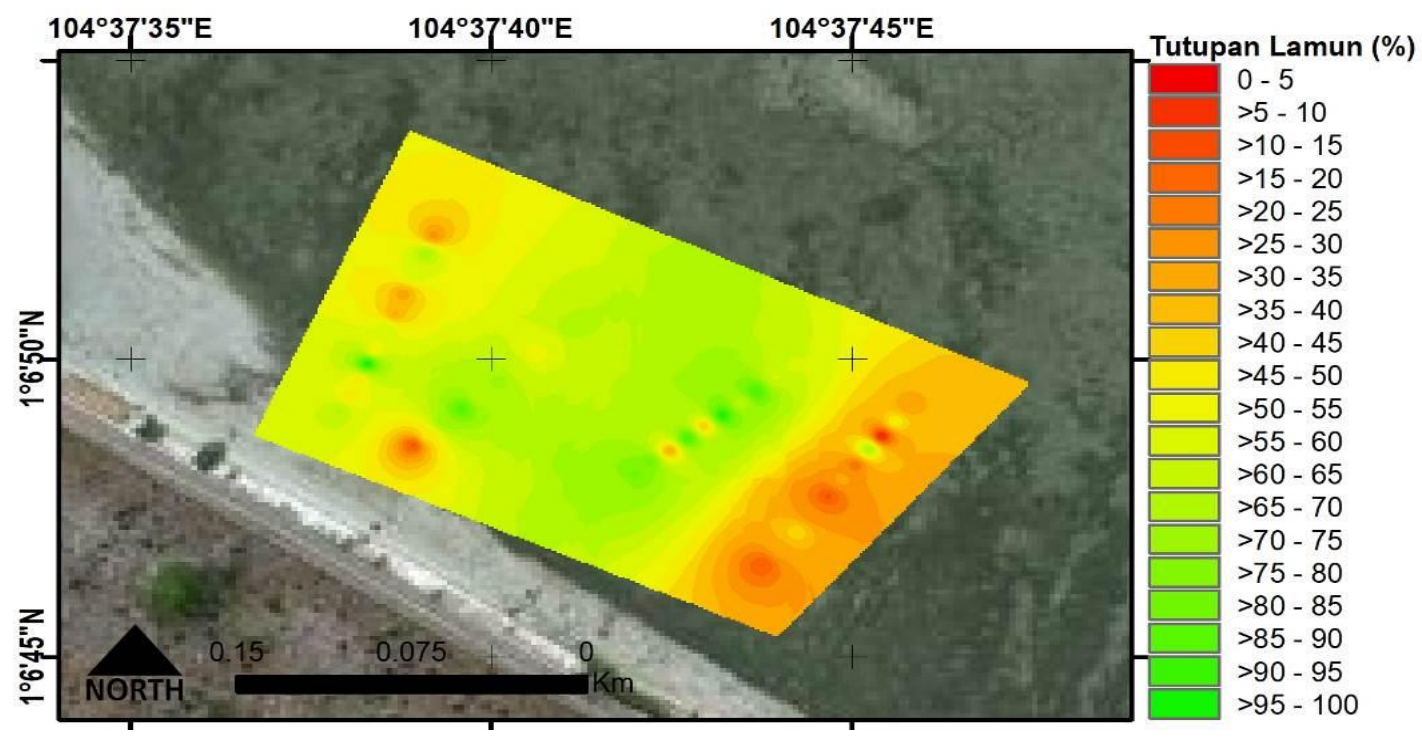

Gambar 2. Persentase Tutupan Lamun di lokasi penelitian, tutupan tinggi ditunjukkan oleh warna hijau.

Tabel 3. Pendataan jenis lamun

\begin{tabular}{lllllllllll}
\hline $\begin{array}{l}\text { Garis } \\
\begin{array}{l}\text { Tran- } \\
\text { sek }\end{array}\end{array}$ & $\begin{array}{l}\text { Rata-rata } \\
\text { Penutu- } \\
\text { pan (\%) }\end{array}$ & Ea & Th & Cs & Cr & Hu & Hd & Si $\begin{array}{l}\text { Kerapa } \\
\text {-tan Ea } \\
\text { (tega- } \\
\text { kan } / \mathrm{m}^{2} \text { ) }\end{array}$ \\
\hline L.01 & 70.17 & 22.16 & 47.44 & 2.27 & 0.28 & 0.57 & 0.28 & 3.41 & 42.91 \\
L.02 & 60.37 & 13.92 & 45.53 & 0.85 & - & 0.43 & - & 0.64 & 33.82
\end{tabular}




\begin{tabular}{|c|c|c|c|c|c|c|c|c|c|}
\hline \multirow{2}{*}{$\begin{array}{l}\text { Garis } \\
\text { Tran- } \\
\text { sek }\end{array}$} & \multirow{2}{*}{$\begin{array}{l}\text { Rata-rata } \\
\text { Penutu- } \\
\text { pan (\%) }\end{array}$} & \multicolumn{7}{|c|}{ Dominansi Jenis (\%) } & \multirow{2}{*}{$\begin{array}{l}\text { Kerapa } \\
\text {-tan Ea } \\
(\operatorname{tega-} \\
\mathrm{kan} / \mathrm{m}^{2} \text { ) }\end{array}$} \\
\hline & & $\mathrm{Ea}$ & Th & Cs & $\mathrm{Cr}$ & $\mathrm{Hu}$ & $\mathrm{Hd}$ & $\mathrm{Si}$ & \\
\hline L.03 & 53.59 & 10.40 & 36.89 & - & 1.09 & 0.57 & 0.02 & 4.57 & 30.91 \\
\hline L.04 & 30.97 & 19.18 & 15.34 & 0.14 & - & - & - & 2.56 & 22.91 \\
\hline $\begin{array}{l}\text { rerata } \\
\text { akhir }\end{array}$ & 53.77 & $\begin{array}{l}16.41^{+} \\
+\end{array}$ & $\begin{array}{l}36.30^{++} \\
+\end{array}$ & 0.82 & 0.34 & 0.39 & $0.08^{+}$ & $2.79^{+}$ & 32.64 \\
\hline
\end{tabular}

Keterangan :

+ = ditemukan (+++ = ditemukan dominan); - = tidak ditemukan.

$\mathrm{Ea}=$ Enhalus acoroides, Th=Thalassia hemprichii, $\mathrm{Cs}=$ Cymodocea serrulata, $\mathrm{Cr}=$ Cymodocea rotundata, $\mathrm{Hu}=$ Halodule uninervis, $\mathrm{Hp}=$ Halodule pinifolia, $\mathrm{Hd}=$ Halophila decipiens, $\mathrm{Si}=S y$ ringodium isoetifolium, $\mathrm{Ho}=$ Halophila ovalis, $\mathrm{Tc}=$ Thallasodendron ciliatum

Gambar 2 dan Tabel 3, menggambarkan kondisi padang lamun di daerah penelitian di Desa Malang Rapat. Menurut kategori penutupan padang lamun berdasarkan Rahmawati et al., (2017) maka daerah penelitian termasuk kategori padat. Dominasi jenis Th dan Ea menggambarkan daerah penelitian adalah daerah yang stabil, kedua jenis tersebut merupakan lamun dengan bentuk yang besar dan membutuhkan waktu yang lama untuk tumbuh besar. Larkum et al, (2006), menjelaskan bahwa tegakan Ea lebih sulit mati dan lebih sulit tumbuh dibandingkan dengan jenis lamun yang lain. Beberapa daerah dengan dominasi Th dan Ea yang besar, merupakan daerah yang tidak terlalu mendapatkan tekanan lingkungan yang besar.

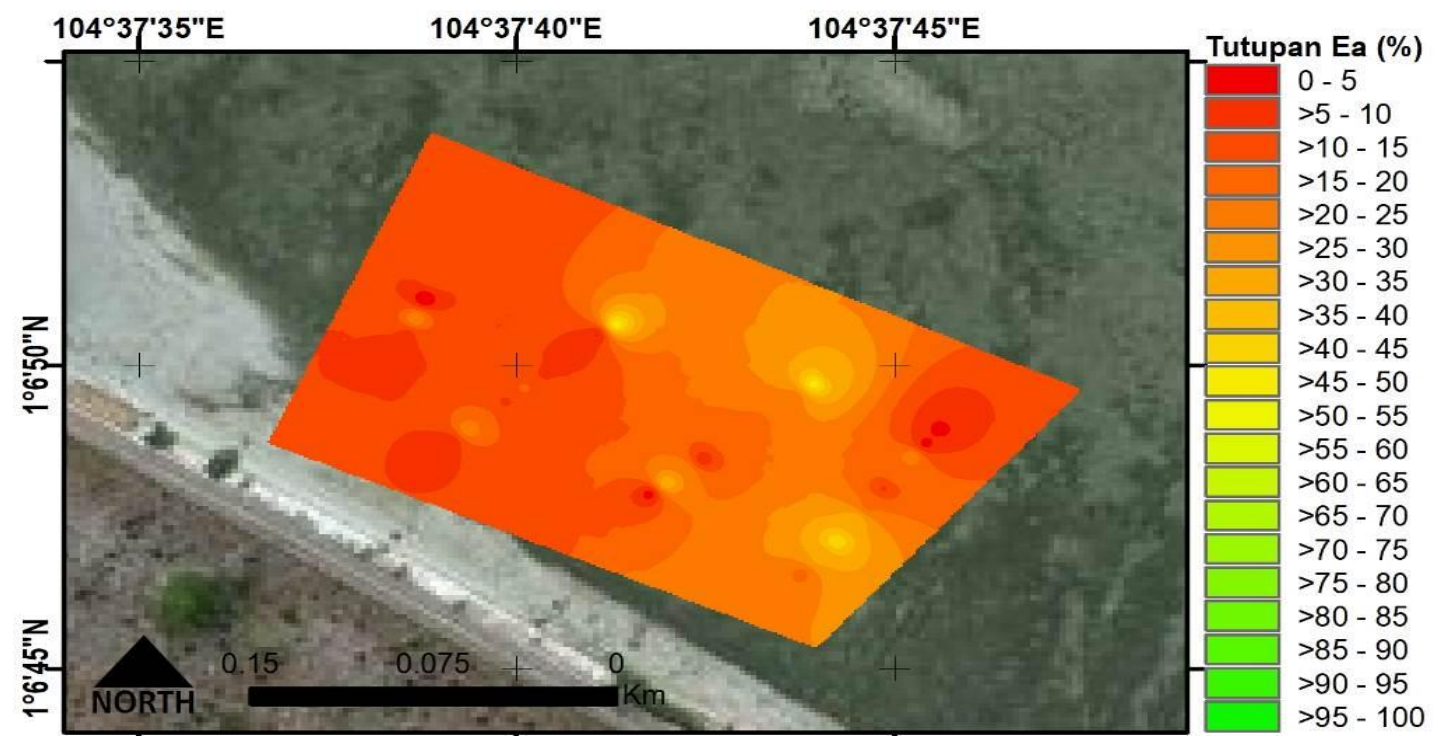

Gambar 3. Peta sebaran dan penutupan lamun jenis Enhalus acoroides (Ea) di lokasi penelitian. Penutupan rata rata Ea adalah $16.41 \%$ 


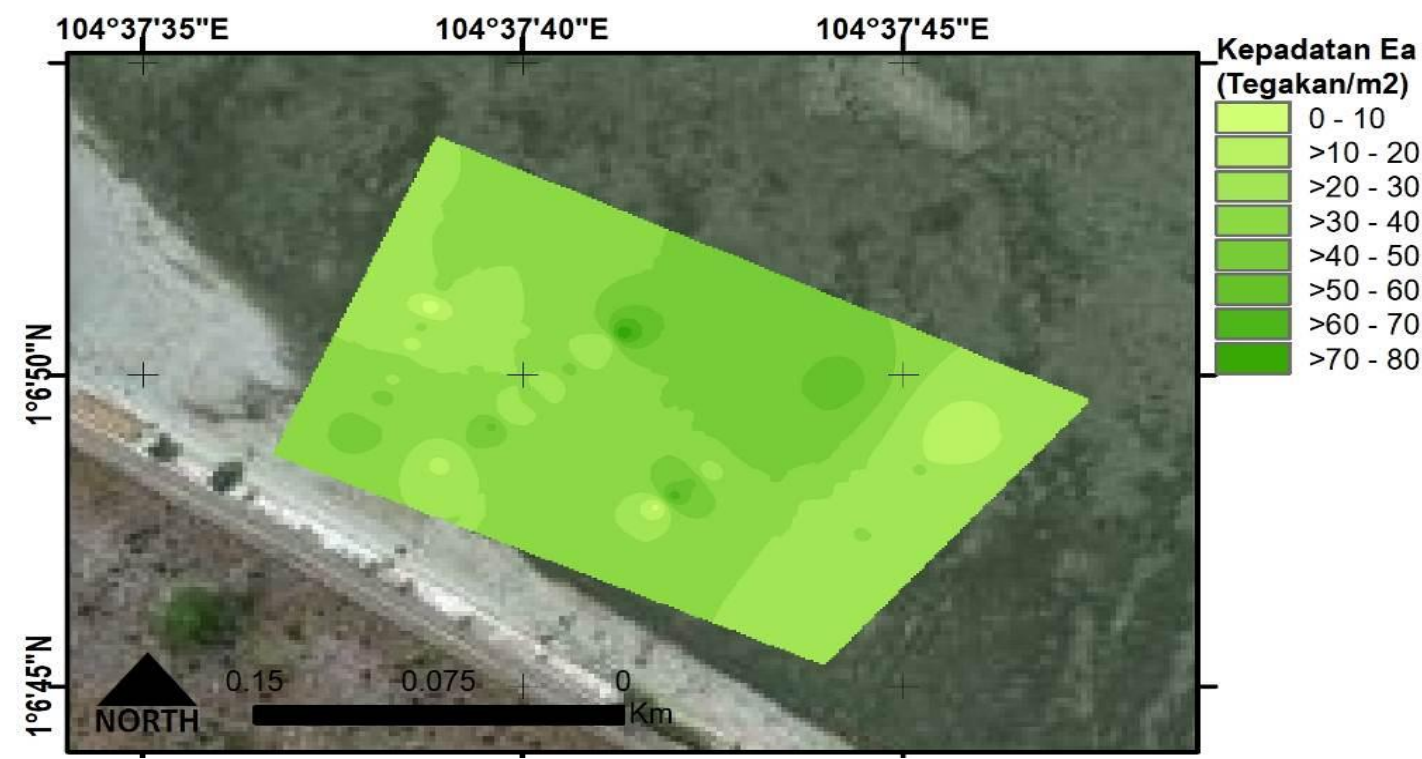

Gambar 4. Kepadatan Lamun jenis Enhalus acoroides (Ea) di lokasi penelitian. Nilai Kerapatan Ea adalah 33 tegakan $/ \mathrm{m}^{2}$ (nilai adalah hasil pembulatan)

Lamun spesies Ea, memiliki persentase penutupan yang selalu kecil di beberapa tempat (Supratman, 2018; Adi, 2007; Adi, 2015), karena jenis ini mempunyai bentuk paling tinggi dari jenis lamun lain yang ditemukan di Indonesia. Jenis Ea lebih banyak memenuhi tinggi kolom perairan dibandingkan menutupi luas dasar perairan. Dalam penelitian ini disajikan rerata tegakan Ea (dengan satuan tegakan $/ \mathrm{m}^{2}$ ) karena lebih menggambarkan kondisi Ea di perairan daripada persentase tutupannya.

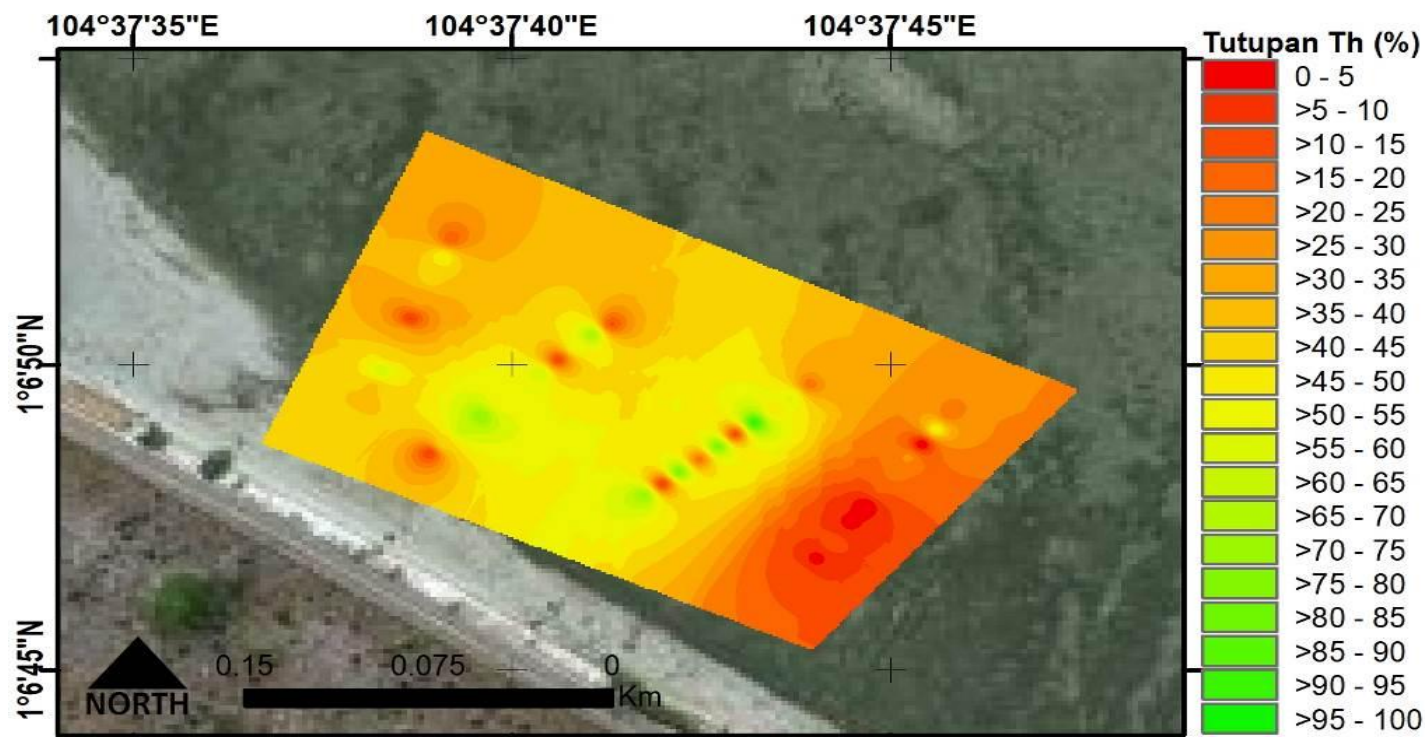

Gambar 5. Peta sebaran dan penutupan lamun jenis Thalassia hemprichii (Th) di lokasi penelitian. Penutupan rata rata Th adalah $36.30 \%$ 
Lamun jenis Th merupakan spesies yang paling dominan. Terlihat di Gambar 5 bahwa sebaran jenis lamun ini memang tinggi, hampir disemua titik pengamatan. Larkum et al, (2006) menjelaskan suksesi lamun di Philipina diawali dari Ho kemudian $\mathrm{Hu}, \mathrm{Cr}$, Cs, Si dan kemudian baru muncul Th dan Ea, hal ini dapat sedikit menjelaskan terjadinya dominasi didaerah penelitian dan hadirnya spesies yang lain saat pengamatan.

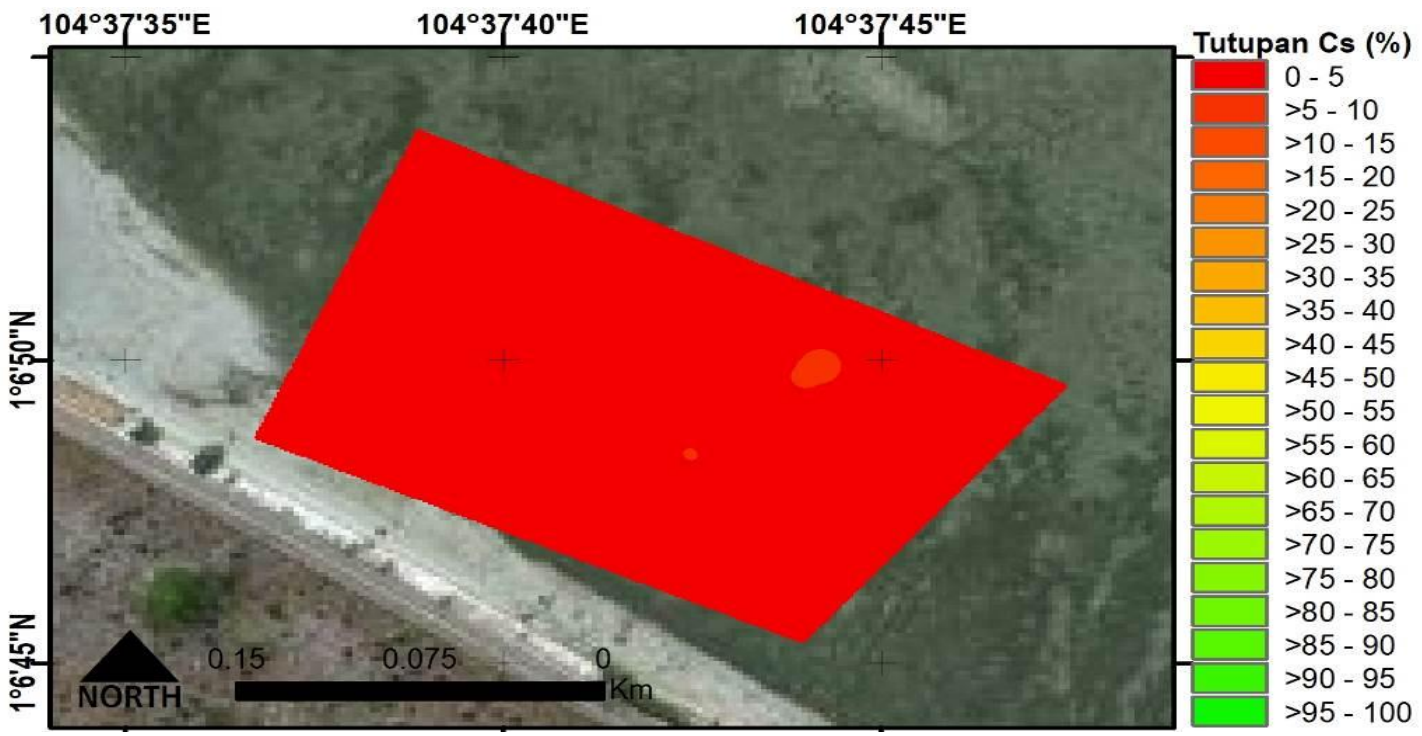

Gambar 6. Peta sebaran dan penutupan lamun jenis Cymodocea serrulata (Cs) di lokasi penelitian. Penutupan rata rata Th adalah $0.82 \%$

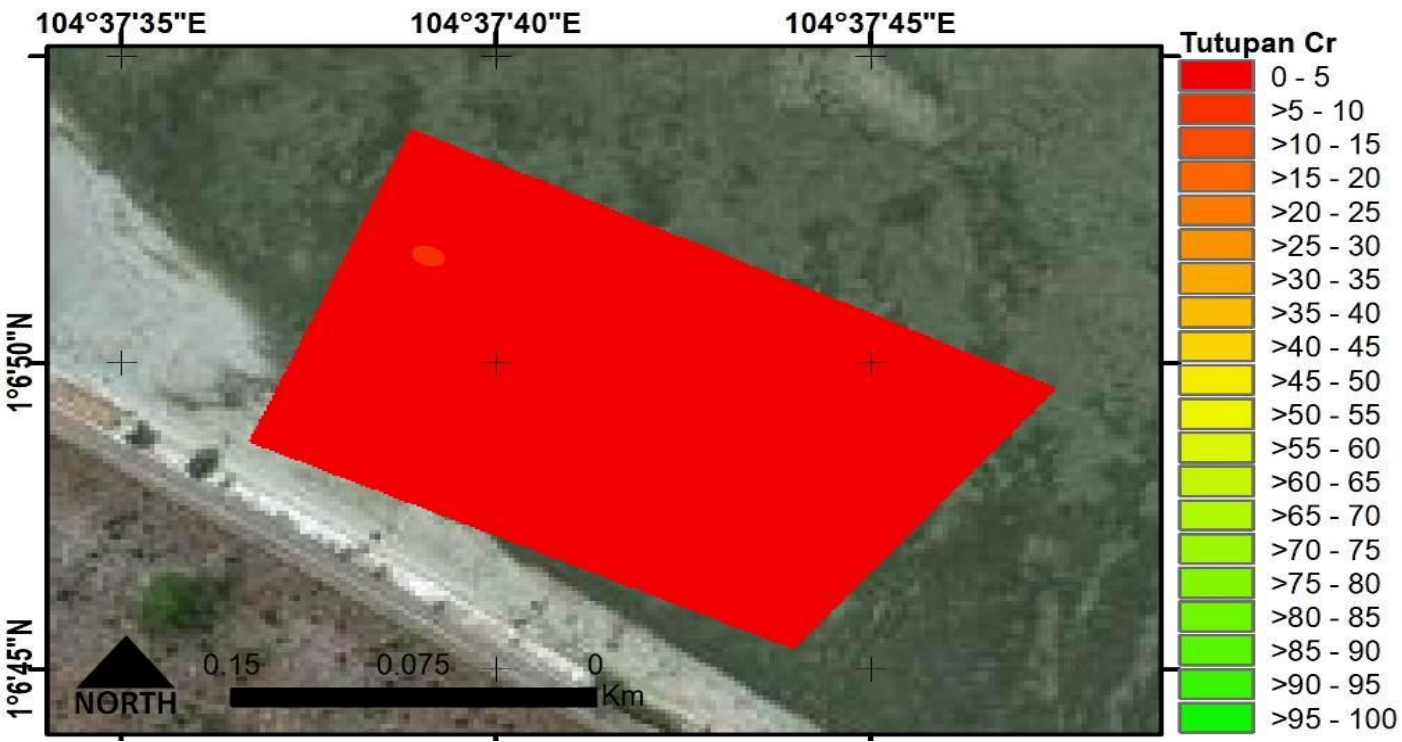

Gambar 7. Peta sebaran dan penutupan lamun jenis Cymodocea rotundata $(\mathrm{Cr})$ di lokasi penelitian. Penutupan rata rata Th adalah $0.34 \%$ 


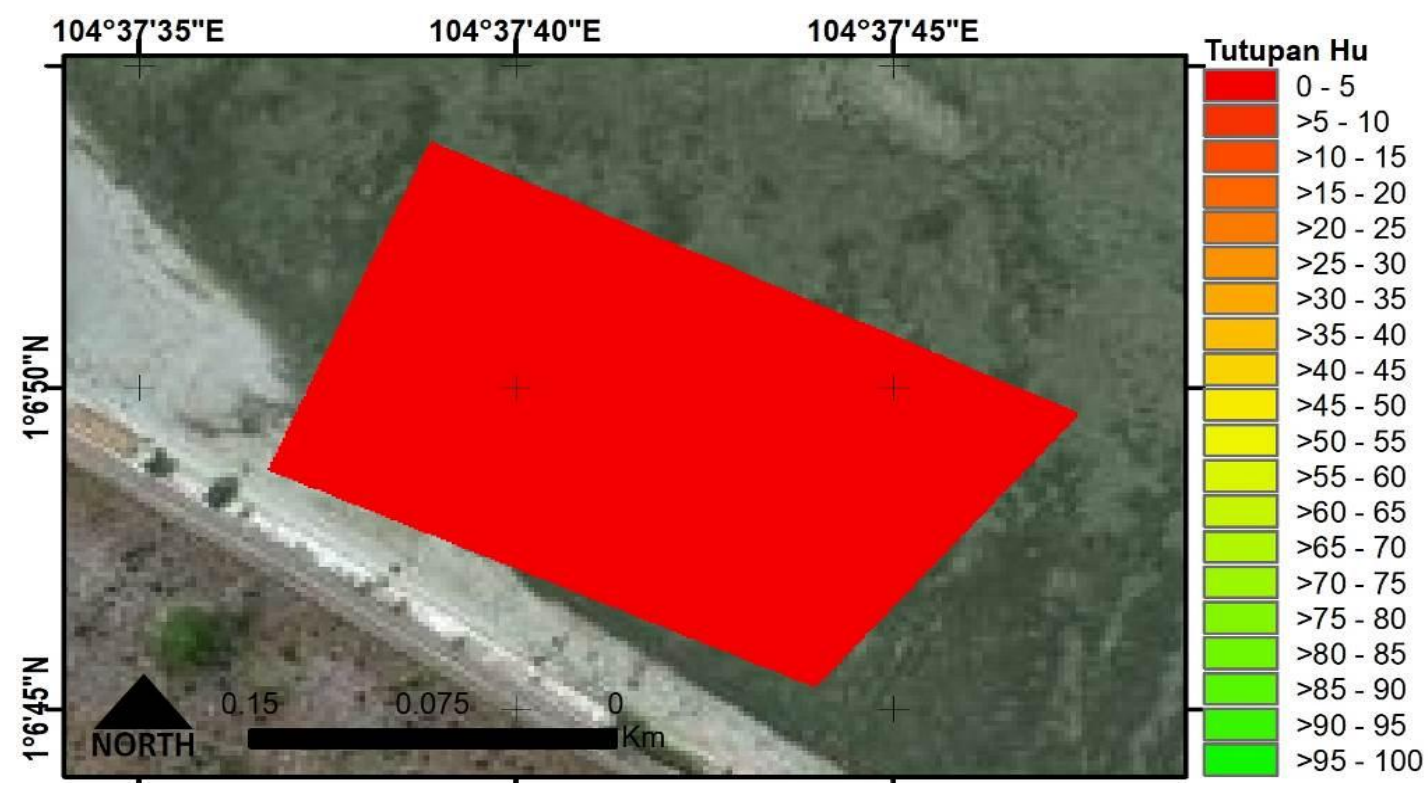

Gambar 8. Peta sebaran dan penutupan lamun jenis Halodule uninervis $\mathrm{Hu}$ ) di lokasi penelitian. Penutupan rata rata Th adalah $0.39 \%$

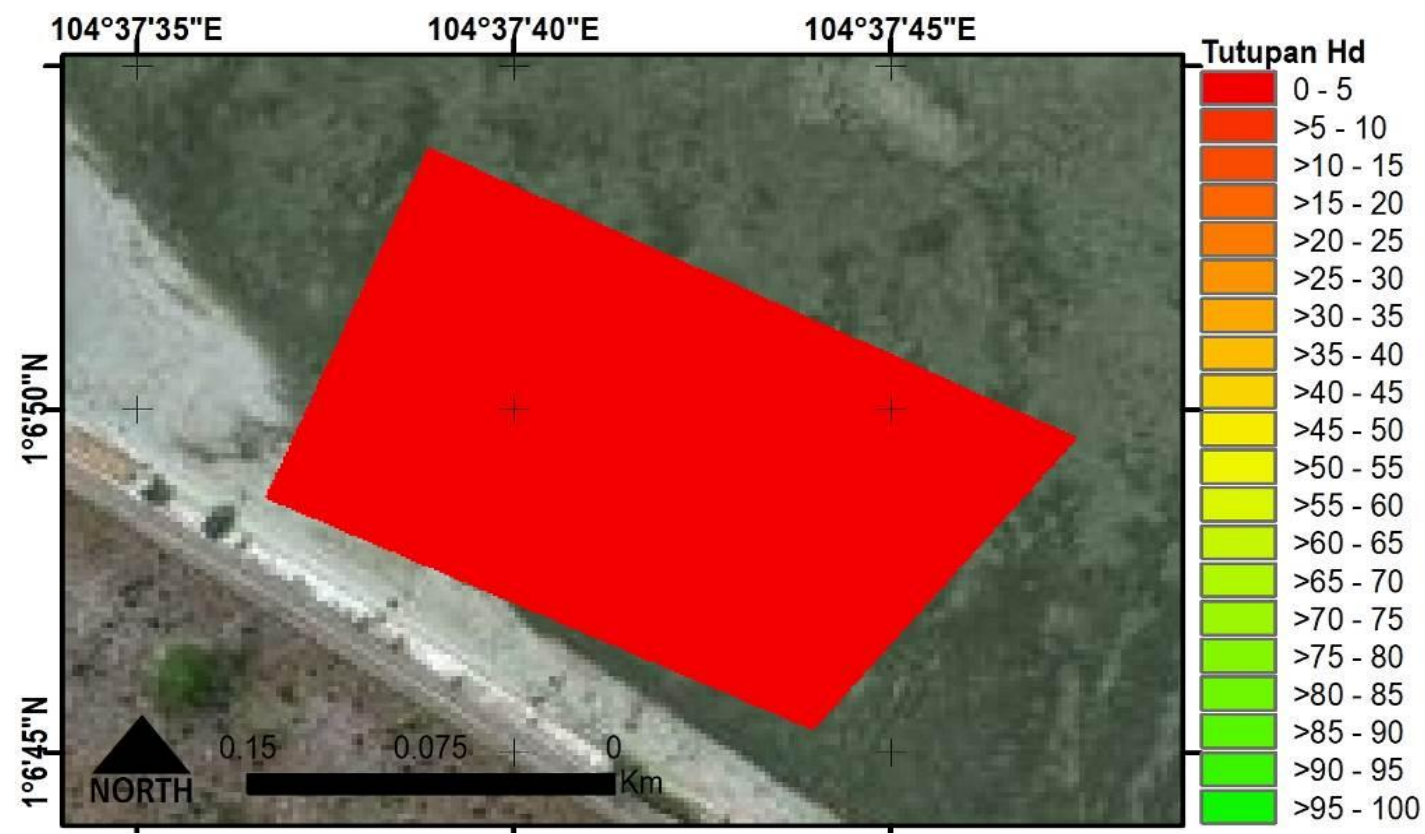

Gambar 9. Peta sebaran dan penutupan lamun jenis Halophila decipiens $(\mathrm{Hd})$ di lokasi penelitian. Penutupan rata rata Th adalah $0.08 \%$ 


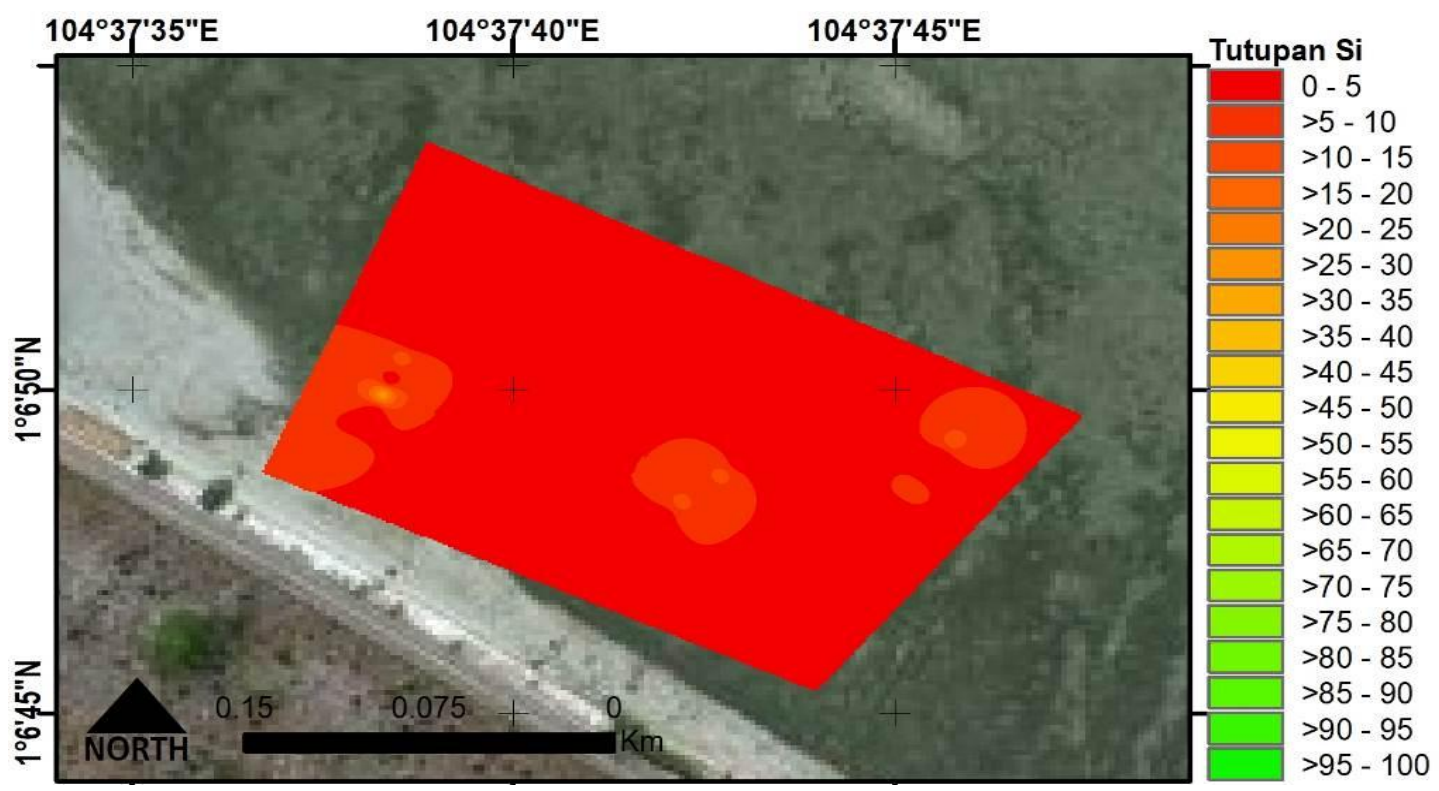

Gambar 10. Peta sebaran dan penutupan lamun jenis Syringodium isoetifolium (Si) di lokasi penelitian. Penutupan rata rata Si adalah $2.79 \%$

Kelima jenis lamun yang lain (Cs, $\mathrm{Cr}, \mathrm{Hu}, \mathrm{Hd}$ dan $\mathrm{Si}$ ) memiliki persentase tutupan yang kecil, di dalam penyajian peta sebaran jenis lamun tidak terlihat variasi warna (yang menunjukkan persentase tutupan lamun). Jenis $\mathrm{Hd}$ dan $\mathrm{Hu}$ dalam lokasi pengamatan sering tertutup oleh jenis Ea dan Th.

\section{KESIMPULAN}

Kondisi padang lamun di daerah penelitian berkategori tutupan padat. Jenis lamun Thalassia hemprichii (Th) dan Enhalus acoroides (Ea) merupakan spesies yang dominan dan menyebar di seluruh daerah penelitian

\section{UCAPAN TERIMAKASIH}

Ucapan terimakasih ditujukan kepada LP2O LIPI, atas diberikannya kesempatan bekerja dan mendapatkan pelatihan mengenai penilaian kondisi padang lamun. Kepada Universitas Bangka Belitung, Universitas Raja Ali Haji, Universitas Sam Ratulangi, Institut Pertanian Bogor dan Universitas Papua kami ucapkan terimakasih atas penugasan yang diberikan. 


\section{DAFTAR PUSTAKA}

Adi, W., 2007. Komposisi dan Kelimpahan Larva dan Juvenil Ikan yang Berasosiasi dengan Tingkat Kerapatan Lamun yang Berbeda di Pulau Panjang, Jepara. Akuatik: Jurnal Sumberdaya Perairan, 1(1), pp.7-11.

Adi, W., 2015. Kajian perubahan luasan padang lamun dengan penginderaan jauh di Pulau Lepar Provinsi Kepulauan Bangka Belitung. Maspari Journal, 7(1), pp.71-78.

Faiqoh, E., Wiyanto, D.B. and Astrawan, I.G.B., 2017. Peranan Padang Lamun Selatan Bali Sebagai Pendukung Kelimpahan Ikan di Perairan Bali. Journal of Marine and Aquatic Sciences, 3(1), pp.1018.

Febrina, M., Adi, W. and Febrianto, A., 2018. Kelimpahan Bivalvia Di Ekosistem Lamun Pantai Puding Kabupaten Bangka Selatan. Akuatik: Jurnal Sumberdaya Perairan, 12(2), pp.64-75.

Kusnadi, A., T.Triandiza and U.E.Hernawan. 2008. Inventarisasi jenis dan potensi moluska padang lamun di kepulauan Kei Kecil, Maluku Tenggara. Biodiversitas 9(1):30-34

Larkum, A.W.D., R.J. Orth, and C.M. Duarte. 2006. Seagrasses: Biology, Ecology and Conservation. Springer Netherlands

Nugraha, A.H., Begen, D.G. and Kawaroe, M., 2017. Physiological response of Thalassia hemprichii on anthropogenic pressure in Pari Island, Seribu Islands, DKI Jakarta. IImu Kelautan, 22(1), pp.40-48.

Prakoso, K., Supriharyono, Ruswahyuni. 2015. Kelimpahan Epifauna di Substrat Dasar dan Daun Lamun Dengan Kerapatan yang Berbeda di Pulau Pahawang Provinsi Lampung. Diponegoro Journal of Maquares. Vol 4 (3) : 11-122.

Prisilia, S., Adi, W. and Febrianto, A., 2018. Struktur Komunitas Ikan Pada Ekosistem Lamun Di Pantai Puding Kabupaten Bangka Selatan. Akuatik: Jurnal Sumberdaya Perairan, 12(2), pp.35-44.

Rahmawati, S., 2011. Ancaman terhadap komunitas padang lamun. Oseana, 36(2), pp.49-58.

Rahmawati, S. Irawan, Andri. Indarto. Supriyadi, Happy. Azkab, Muhammad Husni. 2017. Panduan Pemantauan Penilaian Kondisi Padang Lamun. Jakarta : COREMAP CTI LIPI 
Sjafrie, N.D.M., 2018. Potensi Energi Lamun Untuk Mendukung Pelestarian Dugong (Dugong Dugon) Di Desa Berakit Dan Desa Pengudang Pulau Bintan. Widyariset, 4(2), pp.113-122.

Supratman, O. and Adi, W., 2018. Distribusi dan Kondisi Komunitas Lamun di Bangka Selatan, Kepulauan Bangka Belitung. Jurnal IImu dan Teknologi Kelautan Tropis, 10(3), pp.561-573.

Supratman, O. and Syamsudin, T.S., 2016. Behavior and feeding habit of dog conch (Strombus turturella) in South Bangka Regency, Bangka Belitung islands province. El-Hayah, 6(1), pp.15-21.

Supriadi, La Nafie YA, Burhanuddin Al. 2004. Inventarisasi jenis, kelimpahan dan biomas ikan di padang lamun Pulau Barranglompo Makassar. Torani, 14(5):288-295.

Unsworth, R.K., Ambo-Rappe, R., Jones, B.L., La Nafie, Y.A., Irawan, A., Hernawan, U.E., Moore, A.M. and Cullen-Unsworth, L.C., 2018. Indonesia's globally significant seagrass meadows are under widespread threat. Science of the Total Environment, 634, pp.279286.

Wawo, M., Adrianto, L., Bengen, D.G. and Wardiatno, Y., 2014. Valuation of Seagrass Ecosystem Services in Kotania Bay Marine Nature Tourism Park, Western Seram, Indonesia. Asian Journal of Scientific Research, 7(4), pp.591-600. 